J.D. McKishnie MD, J.M. Muir MB CHB FRCP(C), D.P. Girvan MD MCLSC FRCP(C)

\title{
Anaesthesia induced rhabdomyolysis - A CASE REPORT
}

Anaesthesia-induced rhabdomyolysis (AMR) is a rare bu serious complication of general anaesthesia. We report the occurrence of this event in a previously healthy three-year-old male, with a strongly positive family history of Duchenne muscular dystrophy. Following an uneventful anaesthetic, which included succinylcholine. myoglobinuria developed and led to renal failure which fortunately reversed with conservative reatment, Based on review of reports of similar cases, it is clear that succinylcholine should be avoided in paediatric patients with known myopathy or at high risk for latent myopathy.

Key words

COMPLICATIONS: anaesthesia-induced rhabdomyolysis.
Acute paroxysmal thabdomyolysis with myoglobinuria is a rare event which may be precipitated by a number of "triggers" including drugs, especially the combination of halothane and succinylcholine, used commonly in anaesthesia. ${ }^{1}$ Although the signs and symptoms may resemble an incomplete form (or "forme fruste") of malignant hyperthermia, temperature elevation is not seen. Often patients are found to have a previously clinically inapparent myopathy (most frequently Duchenne muscular dystrophy $\mathrm{DMD}$ ). The following case is presented as it illustrates many of the common features of other reports of rhabdomyolysis or myoglobinuria following general anaesthesia. ${ }^{2-12}$

\section{Case Report}

A previously healthy three-year-old $(18 \mathrm{~kg})$ was anaesthetized for elective orchipexy. Developmental milestones were normal as was physical examination on admission. A positive family history of Duchenne muscular dystrophy was obtained, with two matemal uncles dying from DMD in their early twenties. The mother had had a serum CPK level drawn previously (to establish carrier status) but the value was non-diagnostic (i.e. in the high normal range).

An inhalational induction was employed using $\mathrm{N}_{2} \mathrm{O} / \mathrm{O}_{2}$ and halothane. Subsequently, an IV line was established and atropine $0.1 \mathrm{mg}$ along with succinylcholine $20 \mathrm{mg}$ was given; the patient was intubated without difficulty. The patient was maintained, breathing spontaneously, on halothane and $\mathrm{N}_{2} \mathrm{O} / \mathrm{O}_{2}$ for the duration of the one-hour procedure. The anaesthetic was uneventful as was emergence in the recovery room, and in particular, no temperature elevation was seen at any time.

Postoperatively poor urine output was noted, and over the first 24 hours only a small amount of "tea-coloured" urine was passed. This tested positive for blood and protein (dipstick), but unfortunately none was sent for myoglobin assay. Late 
on the first postoperative day, a significant change in serum potassium was noted as well as BUN and creatinine. At approximately the 48 -hour mark, a capillary sample for $\mathrm{K}^{+}$was reported as $9.7 \mathrm{mEq} / \mathrm{l}$. (N 3.2-5.5). Kayexelate, mannitol and furosemide were administered and the serum potassium level fell promptly, however, urine output remained low $(5-0 \mathrm{cc} / \mathrm{hr})$. Serum CPK was massively elevated at $124,900 \mathrm{u}(\mathrm{N} 120 \mathrm{u})$ as were SGOT and LDH. BUN and creatinine continued to rise over the first four days to peak values of 80 and 4.0 respectively. A peritoneal dialysis catheter was inserted and used briefly; however, renal function gradually returned over the next week. Serum CPK fell to $1,490 \mathrm{u}$ by day 10 , but had risen again to 7,600 u by discharge on day 17.

While recovering from the renal failure, the patient displayed muscle weakness which was characteristic of Duchenne muscular dystrophy. In view of the strong family history, a presumptive diagnosis of DMD was made. Unfortunately muscle biopsy for confirmation was not possible and the patient's family has since been lost to follow-up.

\section{Discussion}

The diagnosis did not become clear in this case until several days following surgery, and although specific identification of myoglobin in the urine was missed, there seems little doubt that acute myoglobinuria secondary to anaesthesia and an underlying myopathy best explains the course of events.

A survey of the literature reveals more than a dozen similar cases ${ }^{2-12}$ occurring in the last 20 years. In all cases myoglobinuria developed following use of succinylcholine. The ages of the patients ranged from three to 20 and the majority were male. In most cases, halothane was the inhalational agent used. In approximately one half of the cases, either the relaxation from succinylcholine was incomplete or a second dose was required for intubation. The intraoperative courses varied from uneventful to cardiac arrest. ${ }^{2,7,9}$ Temperature elevation was rare; invariably the serum CPK was massively elevated (isoenzyme specific for skeletal muscle) as were other enzymes. If renal failure occurred, recovery was the rule. In most, but not all cases, the retrospective diagnosis of myopathy was made, usually Duchenne's; regardless, a familiar pattern of myopathy was noted. Muscle biopsy in most cases was confirmatory for myopathy ${ }^{2,6-9}$ and in the one case where halothane-caffeine contracture was tested, the result was normal. ${ }^{8}$ Another patient in whom $\mathrm{MH}$ could not be diagnosed clinically, was subsequently found to have a positive halothanecaffeine contracture test. ${ }^{22}$

The mechanism of this process is not clearly understood. Theories range from an exaggeration of the normal response to depolarizing ncuromuscular blockade $2,6,8$ to an incomplete form of malignant hyperthermia, ${ }^{10,12}$ It has been shown that the paediatric age group is susccptible to muscle injury from succinylcholine, as evidenced by elevations of serum CPK $^{13,20}$ and by the presence of myoglobin (at least transiently) in the blood. ${ }^{14,19}$ Certain factors have been shown to influence the degree of muscle injury. The injury is increased by a preceding inhalational induction with halothane and by repeat or intermittent doses of succinylcholine. ${ }^{13,20}$ Thiopentone, dantrolene and pre-curarization attenuate the rise in serum CPK. 17,20,21 "Self-taming" doses of succinylcholine do not inhibit the rise, despite reducing visible fasciculations. ${ }^{18}$ This opposes the opinion that fasciculations are responsible for rupture of the muscle cell and outflow of the enzyme. ${ }^{18.20}$ Since most (if not all) of the patients in whom this complication occurs are subsequently shown to have an underlying myopathy, it seems logical that this abnormal muscle may be unusually susceptible to the injury caused by depolarizing blockade and thereby release large amounts of muscle proteins, ions and enzymes. Clinical manifestations could occur early with arrhythmias (or even cardiac arrest) or later as myoglobinuria, with or without renal failure.

On the other hand, the signs and symptoms may be indistinguishable from those of early malignant hyperthermia ${ }^{2,8-10}$ Lack of temperature elevation is significant as is the one report of halothane-caffeine contracture testing with normal results, as previously mentioned. ${ }^{8}$ An association with muscle disease (i.e. strabismus, scoliosis, etc.) is noted for both MH and AIR. ${ }^{12,22}$ We might suggest that some cases, which have been called malignant hyperthermia, or abortive forms thereof, may represent cases of AIR in that no temperature elevation was seen and the crisis was readily reversed. ${ }^{15,16}$ Muscle biopsy for biological assay was unfortunately not done in these cases.

In conclusion, we would like to suggest that succinylcholine be avoided in those patients at bigh 
risk for this complication, by the use of alternate techniques or agents: in particular in the paediatric patient with known or increased likelihood of underlying myopathy. It is not yet established clearly whether anaesthesia-induced rhabdomyolysis should be regarded as an incomplete form of malignant hyperthermia or an exaggerated response to depolarizing blockade; it does appear there is a spectrum of disease ranging from benign to lifethreatening. Treatment (other than supportive) would seem to be mainly that of prevention, as the injury is maximal by the time the diagnosis is made. The development of a non-depolarizing shortacting muscle relaxant for use in children would help reduce the risk of this complication. Finally, it is clear that the anaesthesiologist needs to be aware of the existence and treatment of subtle as well as obvious abnormalities of skeletal muscle precipitated by general anaesthesia.

\section{References}

1 Rowland LP, Penn AS. Myoglobinuria, Med Clin N Am 1972; 56: 1233-56.

2 Schaer $H$, Steinmann B, Jerusalem $S$ et al. Rhabdomyolysis induced by anaesthesia with intra-operative cardiac arrest. Br J Anaesth 1977; 49: 495-9.

3 Bennike KA, Jarum $S$. Myoglobinuria with acute renal failure possibly induced by suxamethonium. Br J Anaesth 1964; 36: 730-6.

4 McLaren $C A B$. Myoglobinuria following the use of suxamethonium chloride. A case report. Br J Ar.acsth 1968; 40: 901-2.

5 Jensen $K$, Bennike KA, Hanel HK, Olesen $H$. Myoglobinuria following anaesthesia including suxamethonium. Br J Anaesth 1968; 40: 329.

6 Moore WE, Watson RL, Summary JJ. Massive myoglobinuria precipitated by halothane and succinylcholine in a member of a family with elevation of serum creatinine phosphokinase. Anaesth Analg 1976; 55: 680-2.

7 Seay AR, Ziter FA, Thompson JA. Cardiac arrest during anaesthesia in Duchenne muscular dystrophy. J Pediatr 1978; 93 : 88.

8 Miller ED, Sanders $D B$, Rowlingson JC, Berry FA, Sussman MD. Epstein RM. Anaesthesia-induced rhabdomyolysis in a patient with Duchenne's muscular dystrophy. Anesthesiology 1978; 48: 146-8.

9 Bolthauser E, Steinmann B, Meyer A. Jerusalem $F A$. Anaesthesia-induced thabdomyolysis in Du- chenne muscular dystrophy. Br J Anaesth 1980; 52 559.

10 Bernhardt D, Hoerder $M H$. Anesthesia-induced myoglobinuria without hyperpyrexia - an abortive form of malignant hyperthermia? Aldrete JA, Britt BA, eds, Malignant Hyperthermia, Grune \& Stratton, New York, 1978; 419-25.

11 Lewandowski $K$. Rhabdomyolysis, myoglobinuria and hyperpyrexia caused by suxamethonium in a child with increased serum creatinine kinase concentrations. Br J Anacsth 1981; 53: 981-4.

12 Lewandowski $K$. Strabismus as a possible sign of subclinical muscular dystrophy predisposing to rhabdomyolysis and myoglobinuria: A study of an affected family. Can Anaesth Soc J 1982; 29:4, 372-6.

13 Innes $R$, Stromme J. Rise in serum creatinine phosphokinase associated with agents used in anaesthesia. Br J Anaesth 1973; 45: 185-90.

14 Ryan J, Kagen L, Hyman A. Myoglobinemia after a single dose of succinylcholine. N Eng J Med 1971; 285: 824-7.

15 Bloom D, Fonkalsrud E, Reynolds $R$. Malignant hyperpyrexia during anaesthesia in childhood. $J$ Ped Surg 1976; 11:2, 185-90.

16 Carballo A. Aborted Malignant Hypcrthermia: A Case Report. Can Anaesth Soc J 1975; 22:2, 22731.

17 Plotz J, Braun J, Stallenberger $R$. The inhibitory effect of dantrolene on the rise of serum creatinine kinase activity after combined use of halothane and suxamethonium in man. Anaesthesist 1981; 30: 338-42.

18 Plotz J, Braun J. Failure of "self-taming" doses of succinylcholine to inhibit increases in postoperative serum creatine kinase activity in children. Anesthesiology 1982; 56: 207-9.

19 Inagaki $M$, Koyama A, Sakata S et al. Serum myoglobin levels following administration of succinylcholine during nitrous oxide - oxygen halothane anesthesia. Jpn J Anesth 1980; 29: 147682.

20 Tammisto $T$, Airaksinen $M$. Increase of creatinine kinase activity in serum as a sign of muscular injury caused by intermittently administered suxamethonium during halothane anaesthesia. $\mathrm{Br} J$ Anaesth 1966; 38: 510-15.

21 Tammisto T, Leikkonen $P$. Airakisinen M. The inhibitory effect of d-tubocurarine on the increase of creatinine kinase activity produced by inter- 
mittent suxamethonium administration during halothane anaesthesia. Acta Anaesthesiol. Scand 1967; 11: 333-40.

22 Tammisto $R$, Brander $P$, Airaksinen $M$, Tommola $V$, Lintola J. Strabismus as a possible sign of latent muscular disease predisposing to suxamethoniuminduced muscular injury. Ann Clin Res 1970; 2: $126-30$.

\section{Résumé}

La rhabdomyolyse causée par l'anesthésie générale (AIR) est une complication rare mais sérieuse. On a constaté un tel cas chez un garçon de trois ans, en bonne santé mais ayant des antécédents familiaux de dystrophie musculaire, type Duchenne. Après le cours normal de l'anesthêsie générale incluant l'usage de la succinylcholine, l' enfant développa ure myoglobinurie qui provoqua une insuffisance rénale. Heureusement, la fonction rénale reprit son cours normal suite à un traitement conservateur. Se basant sur les rapports d'autres cas semblables il est êvident qu'on doit éviter l'administration de succinylcholine chez les enfans auteints de myopathie ou prédisposés à la myopathie.

\section{Errata}

Re: Strunin L, Davies $J M$. The liver and anaesthesia. 1983; 30: 208-17 (March).

The sentence (page 209) "Oxygen consumption is about $1 \mathrm{ml}$ per gram of liver tissue per minute." should read

"Liver blood flow is about $1 \mathrm{ml}$ per gram of liver tissue per minute."

Self-assessment question Number 5, Item 3 (page 218)

should read

"Liver blood flow = about $1 \mathrm{ml} / \mathrm{gm} / \mathrm{minute."}$

The correct answer remains as "B" (Items 1 and 3 correct) 